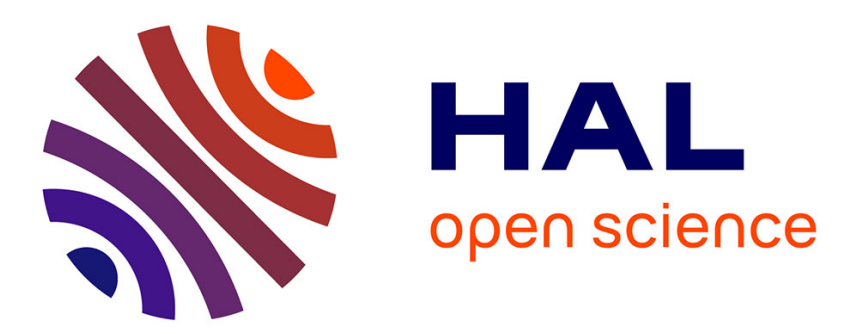

\title{
Maos non-volatile memory structures with lower bandgap storage layer
}

F. Stephany, M. Schumacher, P. Balk

\section{To cite this version:}

F. Stephany, M. Schumacher, P. Balk. Maos non-volatile memory structures with lower bandgap storage layer. Revue de Physique Appliquée, 1978, 13 (12), pp.829-832. 10.1051/rphysap:019780013012082900 . jpa-00244555

\section{HAL Id: jpa-00244555 https://hal.science/jpa-00244555}

Submitted on 1 Jan 1978

HAL is a multi-disciplinary open access archive for the deposit and dissemination of scientific research documents, whether they are published or not. The documents may come from teaching and research institutions in France or abroad, or from public or private research centers.
L'archive ouverte pluridisciplinaire HAL, est destinée au dépôt et à la diffusion de documents scientifiques de niveau recherche, publiés ou non, émanant des établissements d'enseignement et de recherche français ou étrangers, des laboratoires publics ou privés. 


\title{
MAOS NON-VOLATILE MEMORY STRUCTURES WITH LOWER BANDGAP STORAGE LAYER
}

\author{
F. STEPHANY, M. SCHUMACHER and P. BALK \\ Institute for Semiconductor Electronics/SFB 56 « Festkörperelektronik », \\ Technical University, 5100 Aachen, Federal Republic of Germany
}

\begin{abstract}
Résumé. - L'introduction d'une couche mince de $\mathrm{Si}_{3} \mathrm{~N}_{4}$ dans la structure de mémoire MAOS (métal, $\mathrm{Al}_{2} \mathrm{O}_{3}, \mathrm{SiO}_{2}, \mathrm{Si}$ ) augmente le stockage des charges dans la mémoire et réduit les voltages d'inscription pour cette structure MANOS. La recuisson à l'oxygène agit d'une manière significative sur ces propriétés et sur le mécanisme de chargement. Des résultats préliminaires sur la rétention de la charge seront présentés.
\end{abstract}

\begin{abstract}
Introduction of a thin $\mathrm{Si}_{3} \mathrm{~N}_{4}$ layer in metal- $\mathrm{Al}_{2} \mathrm{O}_{3}-\mathrm{SiO}_{2}-\mathrm{Si}$ (MAOS) memory structures leads to increased charge storage capability and reduced writing voltages for these MANOS structures. $\mathrm{O}_{2}$ annealing significantly affects these properties and the charging mechanism. Preliminary results on charge retention are presented.
\end{abstract}

1. Introduction. - Writing and erasure of nonvolatile field effect memory devices with a layered dielectric storage medium takes place primarily by tunneling of charge carriers from the silicon into the conduction or valence band of the outer insulator, or by the reverse process. Because of its unsurpassed dielectric properties thermally grown $\mathrm{SiO}_{2}$ is the logical and nearly unavoidable choise for the inner insulator of the dual dielectric gate system. The need for low writing voltages would dictate that the second insulator of the metal-insulator- $\mathrm{SiO}_{2}-\mathrm{Si}$ combination have a relatively modest bandgap (to reduce the tunneling barrier) and high dielectric constant $\varepsilon$ (to increase the relative field strength across the $\mathrm{SiO}_{2}$ ). On the other hand, suppression of the undesirable charge injection from the metal electrode demands a high internal barrier, necessitating the use of a large bandgap material. These conflicting requirements are best met by using a three layer system [1,2] containing a thin storage layer in addition to the high $\varepsilon$ - large bandgap outer insulator. Kahng and Sze's original device with a thin metal storage film [3], that of Laibowitz and Stiles with small metal particles [4], Horiuchis structure with $\mathrm{Si}$ particles [5] as well as Shuskus' $\mathrm{HfO}_{2}-\mathrm{HfN}-\mathrm{SiO}_{2}$ system [6] belong to this category. Closely related is the MAOS device investigated by Kahng et al. into which deep traps were introduced at the $\mathrm{Al}_{2} \mathrm{O}_{3}-\mathrm{SiO}_{2}$ interface by doping with $\mathrm{W}[7]$ or $\mathrm{WO}_{3}[8]$.

In the present paper we will introduce a three layer memory structure which can be fabricated using standard technology and avoids the charge retention problems encountered with metal interlayers. Our gate system is basically a MAOS structure with $\mathrm{Si}_{3} \mathrm{~N}_{4}$ storage layer; we will designate it as MANOS structure. It combines the advantages of the high dielectric constant of $\mathrm{Al}_{2} \mathrm{O}_{3}$ (9.0 vs 6.2 for $\mathrm{Si}_{3} \mathrm{~N}_{4}$ ) with those of the lower band gap of $\mathrm{Si}_{3} \mathrm{~N}_{4}(5.1 \mathrm{eV} v \mathrm{~s}$ $8.7 \mathrm{eV}$ for $\mathrm{Al}_{2} \mathrm{O}_{3}$ ). The band diagram in figure 1 , which has been composed of the data available for the barriers between the components [1], clearly indicates the potential wells for electrons and holes between the $\mathrm{SiO}_{2}-\mathrm{Si}_{3} \mathrm{~N}_{4}$ and $\mathrm{Si}_{3} \mathrm{~N}_{4}-\mathrm{Al}_{2} \mathrm{O}_{3}$ barriers. We will show that the introduction of this nitride layer increases the amount of charge stored for a given gate voltage and reduces the voltage required to charge the insulator system to a given level.

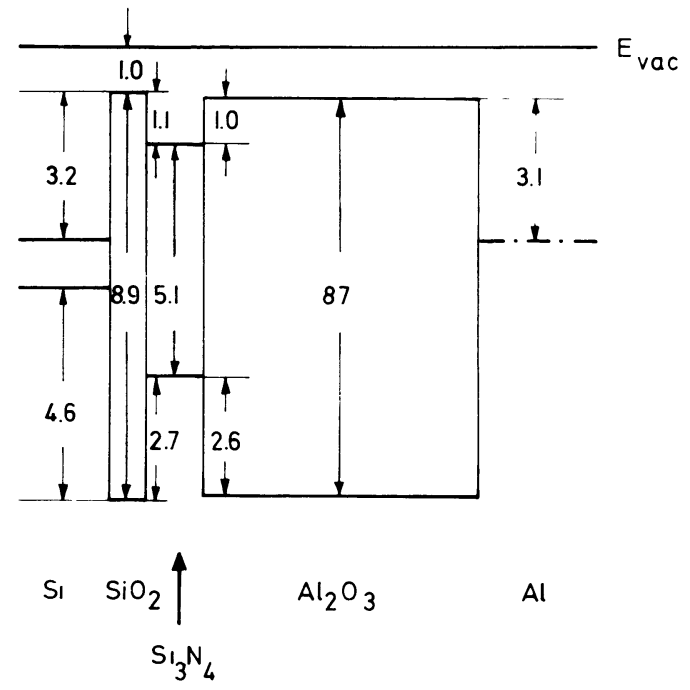

FIG. 1. - Energy band diagram for MANOS structure.

2. Experimental. - MANOS capacitors with various $\mathrm{Si}_{3} \mathrm{~N}_{4}$ thicknesses (including the limiting case MAOS) were fabricated by oxidizing $\langle 100\rangle$ oriented $1 \Omega \mathrm{cm}$ silicon substrates in $10 \% \mathrm{O}_{2} / \mathrm{N}_{2}$ 
followed by deposition of $\mathrm{Si}_{3} \mathrm{~N}_{4}$ from a $0.1 \%$ $\mathrm{NH}_{3} / 1.4 \times 10^{-2} \% \mathrm{SiH}_{4} / 10 \% \mathrm{H}_{2} / \mathrm{N}_{2}$ mixture and of $\mathrm{Al}_{2} \mathrm{O}_{3}$ from a $0.26 \% \mathrm{AlBr}_{3} / 2 \% \mathrm{NO} / 10 \% \mathrm{H}_{2} / \mathrm{N}_{2}$ mixture in different resistance heated furnaces, all at $900{ }^{\circ} \mathrm{C}$. In order to study the effects of subsequent high temperature treatments, a number of samples were annealed in $\mathrm{O}_{2}$ or $\mathrm{N}_{2}$, also at $900{ }^{\circ} \mathrm{C}$. Metallization was carried out by evaporating $\mathrm{Al}$ from an egun apparatus through a mask onto the dielectric system. A 15 min. anneal in $\mathrm{N}_{2}$ at $450{ }^{\circ} \mathrm{C}$ concluded the fabricating cycle.

Film thicknesses were measured ellipsometrically. The $\mathrm{Al}_{2} \mathrm{O}_{3}$ layers were polycrystalline (crystallite size : approx. $10 \mathrm{~nm}$ ) with refractive index 1.75 [8]. For the $\mathrm{Si}_{3} \mathrm{~N}_{4}$ films a value of 1.95 was obtained.

The charge condition of the samples was determined from standard high frequency $\mathrm{C}-\mathrm{V}$ measurements. To obtain realistic conditions the devices were cycled back and forth between the logical states before measuring. The data were obtained by switching from one of these states towards the other.

3. Results and discussion. - When introducing thin $\mathrm{Si}_{3} \mathrm{~N}_{4}$ layers in the MAOS structure the charge uptake for a given pulse height and length increases, as evidenced by the increased magnitude of the logical window (difference between the flatband voltages $V_{\mathrm{FB}}$ for positive and negative gate polarity) in figure 2 . The magnitude of the increase depends on the pulse length and is larger for $\mathrm{O}_{2}$ annealed samples. To facilitate a comparison with other systems the gate voltage has been expressed in terms of the field accross the thin $\mathrm{SiO}_{2}$ film $\left(E_{0 x}^{0}\right)$ in the absence of stored charge. The data for a MNOS capacitor with

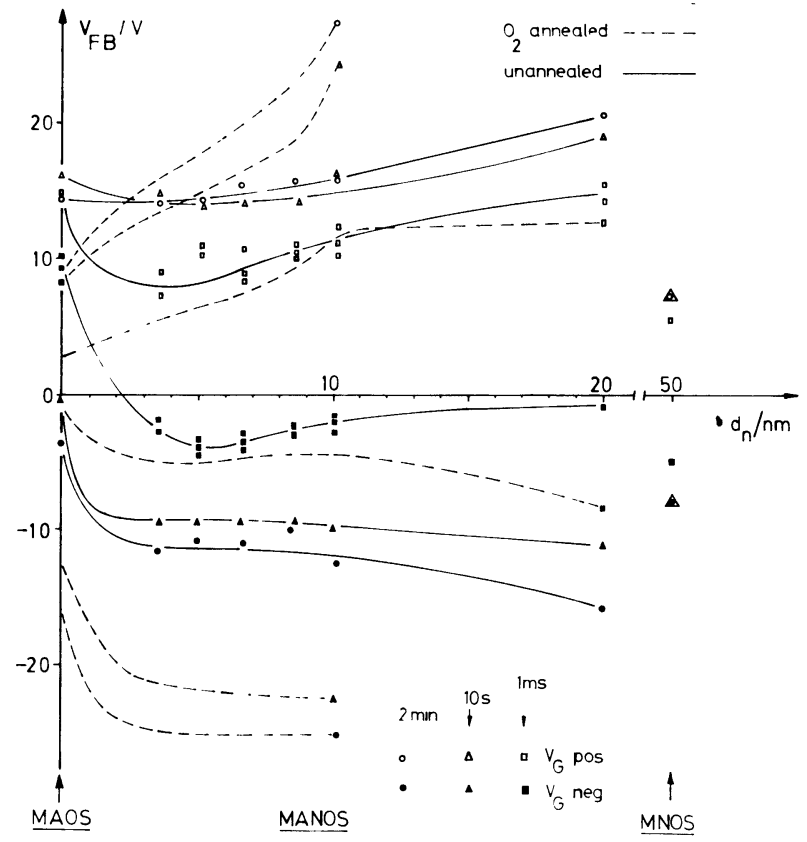

FIG. 2. - Dependence of $V_{\mathrm{FB}}$ on thickness of $\mathrm{Si}_{3} \mathrm{~N}_{4}$ layer for MANOS capacitors. $E_{0 x}^{0}=10 \mathrm{MV} \mathrm{cm}^{-1}$. Data for MAOS and $\operatorname{MNOS}\left(d_{\mathrm{n}}=50 \mathrm{~nm}\right)$ are also shown. Parameter : pulse length; $d_{0 x}=2.5 \mathrm{~nm}$ in all cases $; d_{\mathrm{Al}_{2} \mathrm{O}_{3}}=70 \mathrm{~nm}$. the same $\mathrm{SiO}_{2}$ thickness and total capacitance equal to that of the MAOS structure (i.e. with $d_{\mathrm{n}}=0 \mathrm{~nm}$ ) are also indicated.

Figure 3 shows the $E_{0 x}^{0}$ values required to obtain in 2 min $V_{\mathrm{FB}}$ values of +5 and $-5 \mathrm{~V}$, again for the same range of $d_{\mathrm{n}}$. Interestingly, the unannealed and $\mathrm{O}_{2}$ annealed samples behave in a different manner. The unannealed structures require the larger fields to obtain this $10 \mathrm{~V}$ window. More important, for the unannealed samples $E_{0 x}^{0}$ decreases in a pronounced fashion with increasing $d_{\mathrm{n}}$ for the negative $V_{\mathrm{FB}}$ value, but only very weakly for the positive $V_{\mathrm{FB}}$ value. This behaviour, which was not affected by heating in $\mathrm{N}_{2}$, may be seen to occur for the opposite $V_{\text {FB }}$ polarities upon $\mathrm{O}_{2}$ annealing.

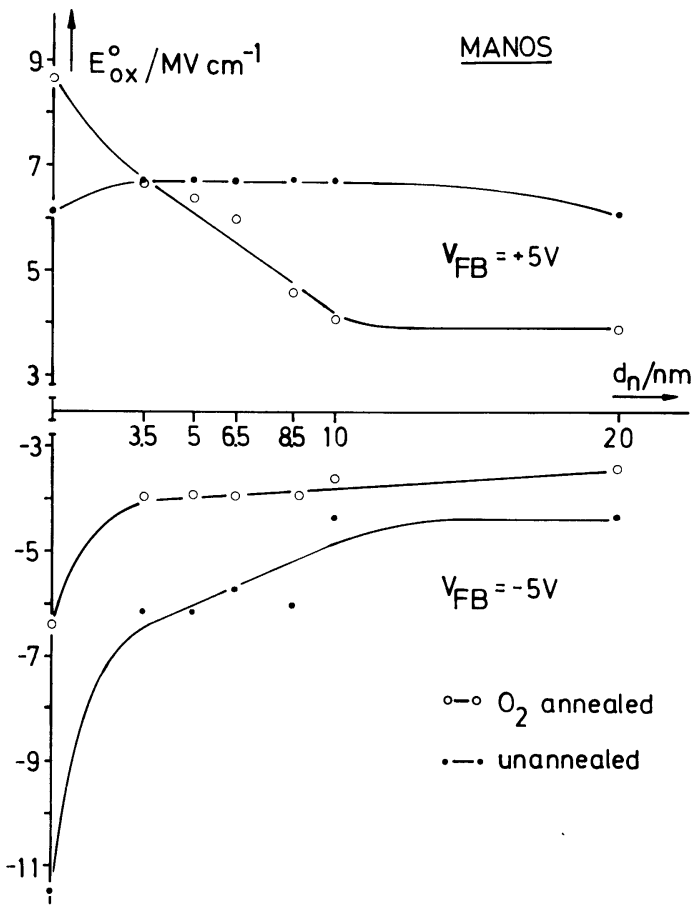

FIG. 3. - Fields $E_{0 x}^{0}$ required for obtaining $\pm 5 \mathrm{~V}$ shift in $V_{\mathrm{FB}}$ for unannealed and $\mathrm{O}_{2}$ annealed MANOS capacitors ; $d_{0 x}=2.5 \mathrm{~nm}$; $d_{\mathrm{Al}_{2} \mathrm{O}_{3}}=70 \mathrm{~nm}$.

We propose that these observations may be explained as follows : the minimum field accross the $\mathrm{SiO}_{2}$ layer required for injection of electrons into the conduction band of the nitride may be shown (Fig. 4) to decrease with increasing thickness $\left(d_{n}\right)$ of the nitride layer :

$$
E_{0 x}^{0}(\min )=\left(\varphi_{1}-\varphi_{2}\right)\left(d_{0 x}+d_{\mathrm{n}} \varepsilon_{0 x} / \varepsilon_{\mathrm{n}}\right)^{-1} .
$$

Upon injection in the conduction band the carriers will move over some distance untill they become trapped. Since the $\mathrm{Si}_{3} \mathrm{~N}_{4}-\mathrm{Al}_{2} \mathrm{O}_{3}$ barrier tends to confine the carriers to the nitride layer, the storage capability at a given $E_{0 x}^{0}$ value should increase. with $d_{\mathrm{n}}$. Fields below $E_{0 x}^{0}(\mathrm{~min})$ would only allow injection into the conduction band of the $\mathrm{Al}_{2} \mathrm{O}_{3}$ or into 


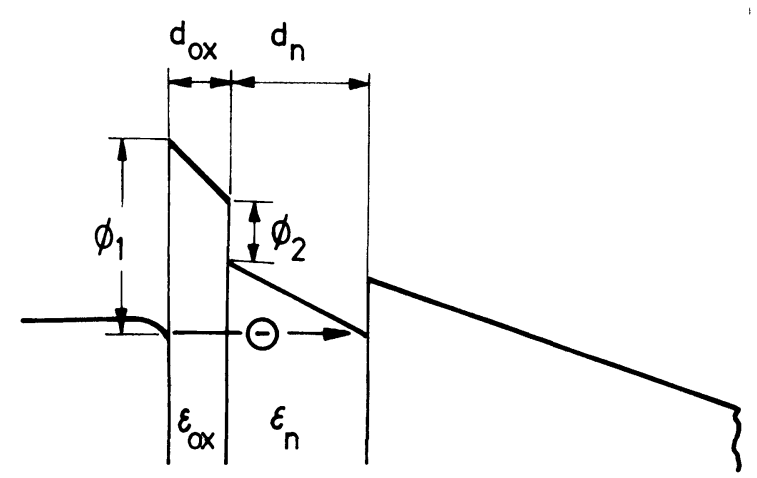

$\mathrm{SiO}_{2}$

$\mathrm{Si}$<smiles>[AsH2]</smiles>

$\mathrm{Al}_{2} \mathrm{O}_{3}$

FIG. 4. - Minimum field required for electron injection in $\mathrm{Si}_{3} \mathrm{~N}_{4}$ layer of MANOS structure.

traps in this material [9]. In this case the tunneling probability and consequently the charging rate should be considerably reduced. Assuming that the rate of the reverse process is determined by the tunneling of electrons through the $\mathrm{SiO}_{2}$ layer one would again expect a low discharging field, but no dependence on $d_{\mathrm{n}}$.

The $\mathrm{O}_{2}$ annealed MANOS capacitors apparently follow this pattern where electrons are the dominant carriers. The low conductivity of $\mathrm{O}_{2}$ annealed $\mathrm{Al}_{2} \mathrm{O}_{3}$ [9] tends to confine the electrons to the nitride layer, which would make the model eminently applicable.

The opposite behavior of the unannealed samples would indicate that in this case holes play an important role in the charging process. For holes the barrier structure of the system is qualitatively the same as for electrons and one expects an equation similar to (1) to hold. Under negative bias electrons are injected at the $\mathrm{Al}$ gate, thereby increasing simultaneously the $\mathrm{Al}^{-} \mathrm{Al}_{2} \mathrm{O}_{3}$ barrier towards electron injection and the field at the $\mathrm{Si}_{-} \mathrm{SiO}_{2}$ interface. Thus the rate of hole injection into the $\mathrm{Si}_{3} \mathrm{~N}_{4}$ is increased [10]; also because of their proximity to the silicon the effect of the positive charges ultimately appears to dominate. It is known, that only in unannealed $\mathrm{Al}_{2} \mathrm{O}_{3}$ the electron injection from $\mathrm{Al}$ plays an important role [11]. In discharging the effect of the negative charge in the $\mathrm{Al}_{2} \mathrm{O}_{3}$ has to be overcome, which requires relatively large fields.

The preliminary charge retention data for MANOS capacitors in figure 5 show that the unannealed

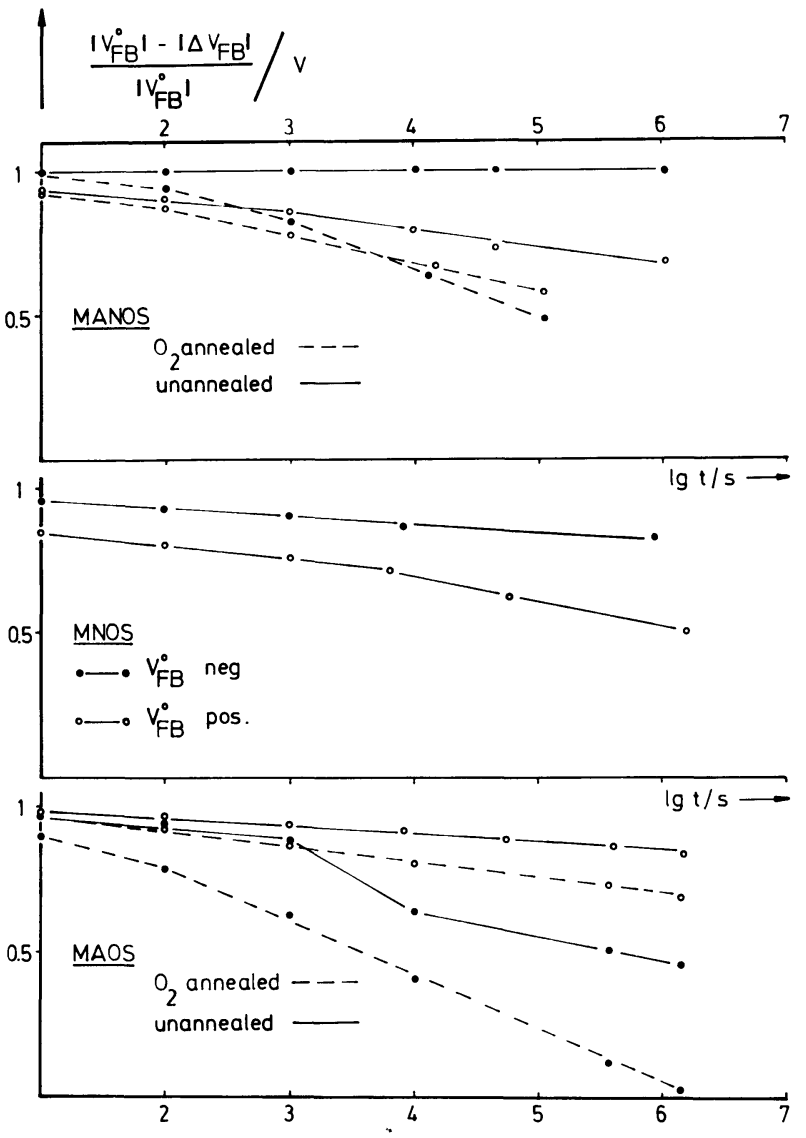

FIG. 5. - Normalized charge loss (room temp.; short circuit) for MANOS $\left(d_{\mathrm{n}}=20 \mathrm{~nm}\right)$, MNOS and MAOS capacitors; $d_{0 x}=2.5 \mathrm{~nm}$ in all cases.

structures hold positive charges $\left(V_{\mathrm{FB}}\right.$ neg.) better than negative ones; in this respect they are comparable to MNOS; MAOS devices exhibit the opposite behavior. Upon $\mathrm{O}_{2}$ annealing the retention capability of MANOS for positive charge decreases to the level for negative charge.

4. Conclusions. - The data in this paper demonstrate the interesting properties of the MANOS structure. These properties are most easily explained for the $\mathrm{O}_{2}$ annealed devices, where the charge storage is mainly determined by the $\mathrm{Si}_{3} \mathrm{~N}_{4}$ layer. In this case electrons are the major carriers. The unannealed structures behave in a more complicated fashion. Here hole injection into the $\mathrm{Si}_{3} \mathrm{~N}_{4}$ also appears to play a role. In both cases the writing voltages are reduced by the addition of the nitride layer. Equating the behavior of MANOS devices with that of MNOS [12] appears to be an oversimplification. 


\section{References}

[1] BalK, P., Solid State Devices 1973 (Inst. of Physics, Conf.) Series 19 (1974) 51

[2] BALK, P., J. Electron. Mat. 4 (1975) 635.

[3] KaHng, D. and Sze, S. M., Bell Syst. Tech. J. 46 (1967) 1288.

[4] Laibowitz, R. B. and Stiles, P. J., Appl. Phys. Lett. 18 (1971) 267.

[5] HoRIUCHI, M., paper presented at I.E.D.M., Washington 1972.

[6] Shuskus, A. J., Quinn, D. J. and Cullen, D. E., Appl. Phys. Lett. 23 (1973) 184

[7] Kahng, D., Sundburg, W. J., Boulin, D. M. and Ligenza, J. R., Bell Syst. Techn. J. 53 (1974) 1723.
[8] Ligenza, J. R., Kahng, D., Lepselter, M. and Labate, E., IEEE Trans. ED-24 (1977) 581.

[9] Kampshoff, H., Stephany, F. and BalK, P., J. Electrochem. Soc. 124 (1977) 1761.

[10] Arnett, P. C. and Dimaria, D. J., Appl. Phys. Lett. 27 (1975) 34.

[11] Balk, P. and Stephany, F., J. Electrochem. Soc. 118 (1971) 1634.

[12] Zirinsky, S. and Irene, E. A., J. Electrochem. Soc. 125 (1978) 305. 